\title{
Animal source food eating habits of outpatients with antimicrobial resistance in Bukavu, D.R. Congo
}

Ghislain Bilamirwa Ngaruka', Brigitte Bora Neema', Theophile Kashosi Mitima', Antoine Sadiki Kishabongo ${ }^{1,2}$ and Olivier Basole Kashongwe 1,3, $^{\text {* }}$ (1)

\begin{abstract}
Background: Antibiotic resistance is a public health concern in Democratic Republic Congo and worldwide. It is usually caused by antibiotic over prescription or dispensing practices. The consumption of animal source food (ASF) could be another source of antibiotic resistance but is rarely studied. The objective of the study was to evaluate the eating habits of ASF by outpatients with antimicrobial resistance through an analysis of (i) the association of their antimicrobial resistance with ASF consumption; (ii) the influence of the types of ASF on their antimicrobial resistance.

Methods: This is a retrospective analytical study conducted at three major Hospitals in Bukavu City (D. R. Congo). A total number of 210 patients, whose samples (mainly faeces and urine) had been subjected to bacterial examination, was included in this study. Morphological, biochemical and antibiotic susceptibility (using disc diffusion method) tests were performed on the samples. This served to isolate and identify resistant bacteria. Afterwards, patients responded to questions about the types and quantity of ASF eaten in the last week. We analysed data using descriptive statistics, logistic regression and non-parametric ranking tests.
\end{abstract}

Results: Escherichia coli (37.1\%), Klebsiella pneumonae (14.7\%), and Staphylococcus aureus (13.8\%) were the most prevalent bacteria. E. coli (68.4\%) and K. pneumonae (87.5\%) were multidrug resistant (MDR), while S. aureus (7.7\%) was minor. Low beef (O.R. 0.737, C.I. 0.542-1.002) and pork (O.R. 0.743, C.I. 0.560 - 0.985) consumption led to significantly $(p<0.05)$ lower risks of resistance to ciprofloxacin. Patients eating three different ASF per week had the highest resistance score (20.67) and high consumption rates of goat meat, pork and milk (41.5\%).

Conclusion: The findings of this study suggest a contribution of human nutrition to antimicrobial resistance frequency. Our results show the existence of a high prevalence of multi-drug resistant bacteria in patients for which eating beef, pork and drinking milk are major risk factors. Therefore, a stricter control of antibiotic usage in livestock production and of their presence in ASF is recommended.

Keywords: Antibiotic resistance, Escherichia coli, Animal Source Foods

*Correspondence: okashongwe@atb-potsdam.de

${ }^{4}$ Leibniz Institute for Agricultural Engineering and Bioeconomy (ATB),

Max-Eyth-Allee 100, 14469 Potsdam, Germany

Full list of author information is available at the end of the article

(c) The Author(s) 2021. Open Access This article is licensed under a Creative Commons Attribution 4.0 International License, which permits use, sharing, adaptation, distribution and reproduction in any medium or format, as long as you give appropriate credit to the original author(s) and the source, provide a link to the Creative Commons licence, and indicate if changes were made. The images or other third party material in this article are included in the article's Creative Commons licence, unless indicated otherwise in a credit line to the material. If material is not included in the article's Creative Commons licence and your intended use is not permitted by statutory regulation or exceeds the permitted use, you will need to obtain permission directly from the copyright holder. To view a copy of this licence, visit http://creativecommons.org/licenses/by/4.0/. The Creative Commons Public Domain Dedication waiver (http://creativeco mmons.org/publicdomain/zero/1.0/) applies to the data made available in this article, unless otherwise stated in a credit line to the data. 


\section{Background}

Bukavu is a fast-growing city in the South-Kivu Province, located in the East of the D.R. Congo. It was benefiting highly from the improvement of security in recent years. Strategically located at the shores of Lake Kivu, the city is supplied with Animal Source Food (ASF) from major local producing hubs as well as across the borders of Rwanda and Burundi [1]. The growing population coincides with increased ASF consumption, while production levels remain low within the country (Robinson and [2,3]. This situation incentivise transboundary import of livestock and products to Bukavu, which quality and safety is not always ascertained. Three major local sources of ASF to Bukavu are existing, including Goma (Northern Kivu), Plaine de Rusizi (South Kivu), and Kavumu (South Kivu). Across borders, Bukavu is supplied with ASF from Kamembe (Rwanda), Burundi (via Uvira), and Uganda (via Goma or Kamembe). Imported products vary in quality and may pose a risk for consumers' health and safety, if no proper control is applied. Indeed, food borne disease outbreaks including diarrhoea, cholera, and typhoid are increasing in number and severity in the Country $[4,5]$. Globally, foodborne diseases are responsible for 1 of 3 deaths and diarrhoeal diseases account for $70 \%$ of total foodborne diseases mainly caused by Salmonella and Escherichia coli. Mahangaiko et al. [6] reported a contamination range of 11 to $27 \%$ of Salmonella spp along the meat chain in Kinshasa. Antimicrobial residues in ASF and associated development of resistance in people in D.R. Congo has not gained sufficient attention to shed light on the potential danger. Among the few available studies, Irenge et al. [7] reported a range of 20 to $100 \%$ resistance of E. coli, Salmonella, Staphylococcus aureus and Coagulase Negative Staphylococci isolates from patients to a wide range of antibiotics including those commonly used for livestock treatment: quinolones, sulfamides, tetracyclines and $\beta$-lactams. The developed resistances are often attributed to an uncontrolled use of antibiotics by patients and the transfer of acquired resistance to antimicrobials from agriculture to humans, which is more and more evident [8]. The European Union has developed a framework to control the use of anti-microbials in agriculture to prevent the transfer of resistances to people [9]. In Africa, specifically in West and East Africa, pathogenic microorganisms, pesticides residues and aflatoxins have gained attention recently in food safety regulations [10]. In the D.R. Congo, no specific approach is present to control the use of antimicrobials in agriculture. This could be directly associated with the consumption of ASF by patients admitted to major hospitals in Bukavu. We hypothesize that regular consumption of contaminated ASF from antibiotic-treated livestock could be associated with enhanced antibiotic resistance in patients in Bukavu town. We base this hypothesis on the potential causal relationship between consumption of ASF, foodborne disease and health status of households described by Randolph et al. [11].

\section{Methods \\ Study setting}

The study used a cross-sectional design to sample outpatients from 3 health zones (corresponding to 3 estates) of Bukavu city in D.R. Congo. Three hospitals, namely, Provincial Referral General Hospital of Bukavu, Referral General Hospital of Panzi and Biopharm Hospital were retained as study sites. The study was conducted between March and May 2019. We included outpatients sent by their practising physician to laboratories of the selected hospitals for antibiogram tests and interviewed them afterwards.

\section{Data collection and processing}

During the months of March to May, a total of 210 outpatients who attended the selected hospitals were recruited for the study. The selection of the random sample of 210 patients followed recommendations to obtain an effective sample size of $15-20 \%$ of the total population under study (<4000 patients visited the laboratory facilities of the selected hospitals for antibiogram test during the study period) with $95 \%$ confidence level and 0.05 precision level [43, 42].

After obtaining their informed consent, we interviewed patients about their meat and milk eating habits. This included the type of ASF (beef, chicken, goat, pork, and milk), the weekly frequency of consumption and the estimated quantity. The quantity, described as the number of portions, was then converted in grams and multiplied by the frequency of consumption to obtain the weekly ASF intake as described by Sanusi and Olurin [12]. This allowed us to categorise the weekly ASF consumption as low or high based on quantitative measures. Respondents eating less than $200 \mathrm{~g}$ of each ASF per week were considered as not regular consumers, while others were considered as frequent consumers, according to Bauer et al. [15]. We also collected data from patients' socio-demographic characteristics, as well as bacteriological results from the laboratory analyses.

Laboratory tests practiced in the selected hospitals consisted of the isolation of causative organisms and in-vitro susceptibilities to several antibiotics. Samples were composed of urine (45\%), faces (35\%) and others, 
including blood and pus (20\%). Isolation of causative microorganisms is routinely conducted using differential plating on specific selection media, including MacConkey Agar, EMB Agar, Baird Parker Agar, DTC Agar, Bile Esculin Agar and XLD Agar. Further morphological and biochemical tests, including Gram's stain, oxidase, catalase, gas production, urease, motility, hemolysis and gelatinase test for each suspected organism were performed [14]. The disk diffusion method was used for antibiotics susceptibility test, following the procedure outlined by Bauer et al. [15] and updated by CLSI [16]. Briefly, bacterial isolates were inoculated in Mueller Hinton Agar plates before antibiotic disks were placed in the plates and incubation conducted for $24 \mathrm{~h}$. Inhibition zone was then read using a measuring calliper [16]. The antibiotics tested included: ciprofloxacin (CIP); norfloxacin (NOR); gentamycin (GEN); amikacin (AMK); ceftriaxone-cefotaxime (CRO_CTX); ceftazidime (CAZ); cefuroxime (CXM); impinem (IPM); meropenem (MEM); tetracycline (TET); doxycycline (DOX); oxacyline (OXA); piperacillin (PIP); clarithromycin (CLR); erythromycin (ERY); clindamycin (CLI); chloramphenicol (CHL); and vancomycin (VAN). No invasive procedure was performed on the patients of this study, because we referred to the results of the above-mentioned laboratory tests.

\section{Statistical analysis}

Data processed in MS Excel 2007 were analysed using descriptive and inferential statistics in SPSS version 22. Descriptive statistics were used first with frequencies and percentages to describe the socio-demographic data, as well as occurrence and antibiotic resistance of isolated microorganisms. We also used descriptive statistics to compute the multidrug resistance of bacterial isolates, on the basis of resistance to 3 or more antibiotic groups. Means and standard deviation were used to describe consumption trends of ASF. We used logistic regression to assess the association between ASF consumption and antibiotic resistance of respondents, for which we computed the Odds Ratio (O.R.) and Confidence Interval (C.I.). We set "high consumption" as the reference value $(=1)$. The Hosmer and Lemeshow test was used to assess the model fit at the significance level of 5\%. We finally used non parametric ranking tests to determine the influence of the number of ASF eaten on the observed resistance to antibiotics. The sum of scores, mean scores and P-values (bold) are reported.

\section{Results}

Socio-demographic characteristics and ASF consumption of respondents

Mean age of respondents was $46 \pm 11.5$ years and female was the predominant sex (58\%). More than half of
Table 1 Description of socio-demographic characteristics of respondents $(n=210)$

\begin{tabular}{lll}
\hline Parameter & N & $\%$ \\
\hline Sex & 122 & \\
Female & 88 & 58.1 \\
Male & & 41.9 \\
Age & 59 & 28.1 \\
18-22 & 48 & 22.0 \\
23-31 & 34 & 16.2 \\
32-40 & 53 & 25.8 \\
$>40$ & & \\
Commune & 41 & 19.0 \\
Bagira & 124 & 59.0 \\
Ibanda & 45 & 21.4 \\
Kadutu & & $92.8(33.7)$ \\
High ASF consumption & $195(67)$ & $90.0(13.1)$ \\
Beef & $190(26)$ & $61.0(58.0)$ \\
Chicken & $165(40)$ & $96.6(65.8)$ \\
Goat & $128(76)$ & $98.0(38.3)$ \\
Pork & $203(135)$ & \\
Milk & $881(344)$ & \\
Overall & & \\
\hline
\end{tabular}

respondents (59\%) were from the commune of Ibanda while only $19 \%$ came from Bagira. The majority (98\%) of respondent stated they had eaten ASF at least once in the past week, but only $38.3 \%$ had high ASF consumption (Table 1).

Results summarizing consumption of animal -source -food (ASF) by respondents are presented in Fig. 1. The average consumption of beef and milk were above $250 \mathrm{~g}$ per person per week for high consumers, while low consumers ate between 50 to $100 \mathrm{~g}$ of ASF per week on average (Fig. 1).

Results of microbial cultures from patients' samples are presented in Table 2. Escherichia coli (37.1\%), Klebsiella spp (14.7\%) and S. aureus (13.8\%) were the most observed bacterial species. Klebsiella oxytoca (0.9\%) and Salmonella spp $(0.9 \%)$ were the least observed ones.

Table 3 presents the results of the antibiotic resistance profiles of bacterial pathogens accounting for at least $2.5 \%$ of total isolates. The Findings indicate that E.coli isolates were resistant to most antibiotics tested, except amikacin, ciprofloxacin, chloramphenicol and tetracycline, for which less than $42 \%$ of samples showed resistance. Ciprofloxacine was the most tested antibiotic with $14.7 \%$ (90 tests).

Results in Table 4 present the antimicrobial resistance of the isolates from patients' samples. We found that all Morganella spp, Pseudomonas spp and Serratia spp isolates were multidrug resistant as well as $68 \%$ of E. coli 


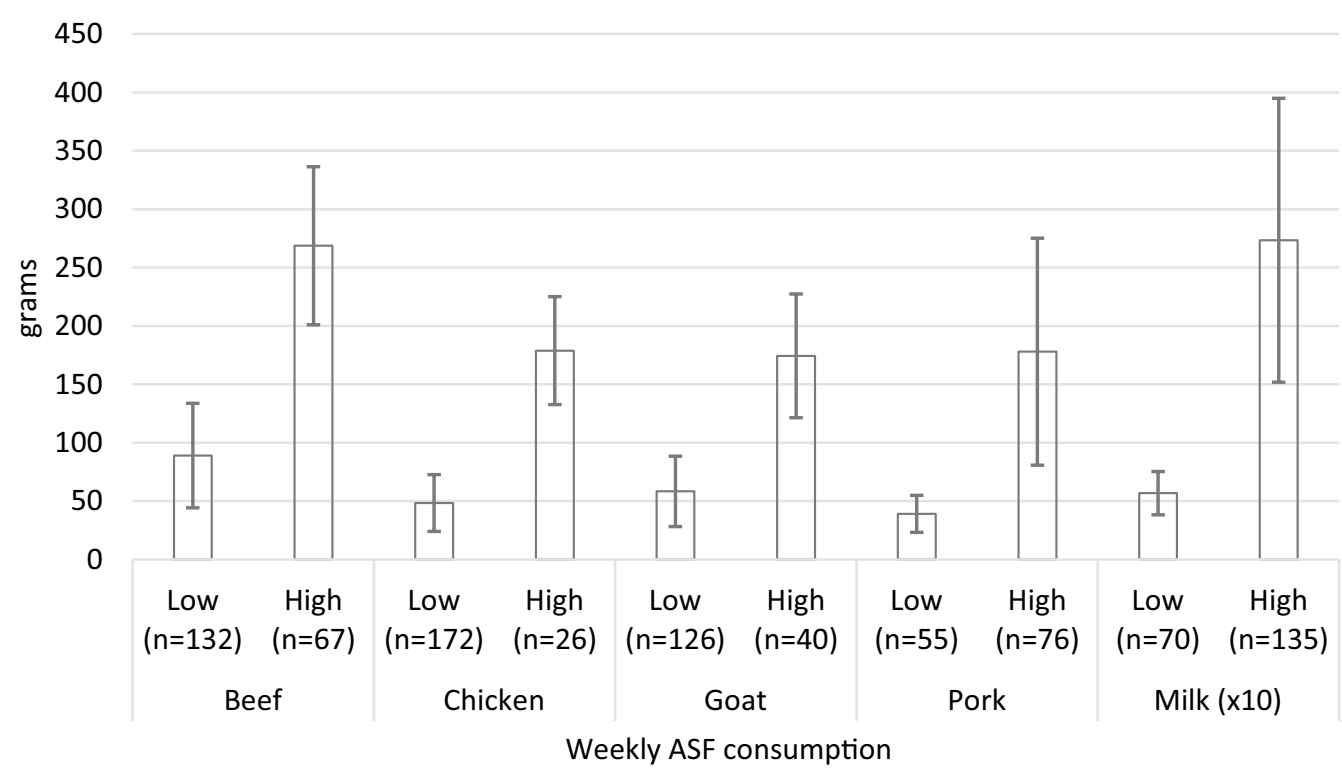

Fig. 1 Consumption trends of animal Source Food (ASF) in Bukavu City. Milk consumption values are expressed in $10 \times$ grams

Table 2 Occurrence of bacteria in patients' samples

\begin{tabular}{lll}
\hline Bacteria & Isolates & \\
\cline { 2 - 3 } & $\mathbf{n}$ & $\%$ \\
\hline Escherichia coli & 43 & 37.1 \\
Klebsiella pneumonae & 17 & 14.7 \\
Staphylococcus aureus & 16 & 13.8 \\
Enterococcus spp & 11 & 9.5 \\
Enterobacter spp & 8 & 6.9 \\
Candida albicans & 7 & 6.0 \\
Morganella spp & 3 & 2.6 \\
Serratia marcescens & 3 & 2.6 \\
Pseudomonas spp & 2 & 1.7 \\
Cagulase Negative Staphylococcus & 2 & 1.7 \\
Streptococcus spp & 2 & 1.7 \\
Klebsiella oxytoca & 1 & 0.9 \\
Salmonella spp & 1 & 0.9 \\
Total & 116 & 100 \\
\hline
\end{tabular}

isolates. On the other hand, All C. albicans, K. oxytoca, Salmonella spp, CNS, Streptococcus spp isolates did not show multidrug resistance.

Table 5 presents the association between the detected antimicrobial resistances in patients and the ASF eaten, either high (Reference) or low as presented in Fig. 1. Patients eating less beef (O.R. 0.737; C.I. 0.542-1.002) and pork (O.R. 0.743; C.I. $0.560-0.985)$ had significantly $(p<0.05)$ lower odds of resistance to ciprofloxacin compared to those regularly eating. The odds of resistance to gentamicin was significantly influenced $(p<0.05)$ by milk consumption (O.R. 0.234; C.I. 0.059-0.924) in the univariable analysis. The odds of resistance to levofloxacin was significantly associated with beef (O.R. 0.690; C.I. 0.553 - 0.893) and chicken (O.R. 1.965; C.I. 1.370 - 2.820) consumption in the multivariable analysis.

Results of antibiotic resistance scores based on the weekly quantity and types of ASF eaten are presented in Table 6. The majority of respondents (70.7\%) ate at least two different ASF types in last week. Among the patients who reported eating only one ASF in the last week, $62 \%$ drunk milk, while the combinations of beefmilk (46\%), goat-pork-milk (41.5\%) and beef-chickengoat-pork (50\%) were mostly used in the other categories. The resistance score was highest for the combination of 3 ASF (score $=20.67$ ), followed by the combination of two (19.67) and one ASF (18.89).

\section{Discussion}

The study investigated the question, whether antimicrobial resistance currently observed in patients of Bukavu City could be associated to the eating habits of ASFs. Recent studies report high levels of resistance to antimicrobials in patients visiting hospitals in the city $[7,17,18$, 40]. The increasing trend of resistance to antimicrobials in patients could be reasoned by the widely spread selfmedication and the lack of clear governmental regulations for the use of antibiotics [17, 18, 40]. Additionally, there is growing concern about the contribution of food from animal origin on the observed resistances to antibiotics in humans. Indeed, evidence from other studies 
Table 3 Antibiotic resistance profiles of major bacterial pathogens isolated in patients' samples

\begin{tabular}{|c|c|c|c|c|c|c|c|c|c|}
\hline Antibiotic & n (\%) & $E C(\%)$ & $E B(\%)$ & $E C p(\%)$ & $K P(\%)$ & MS (\%) & $S A(\%)$ & $S P(\%)$ & $S M(\%)$ \\
\hline \multicolumn{10}{|c|}{ Fluoroquinolones } \\
\hline CIP & $90(14.7)$ & 41.9 & 50 & 81.8 & 61.5 & 66.7 & 26.7 & 0 & 100 \\
\hline NOR & $35(5.7)$ & 61.5 & NT & 100 & 0 & NT & 100 & 100 & 66.7 \\
\hline \multicolumn{10}{|c|}{ Aminoglycosides } \\
\hline GEN & $64(10.5)$ & 58.3 & 57.1 & 100 & 62.5 & 100 & 28.6 & 0 & 0 \\
\hline AMK & $39(6.4)$ & 30 & 0 & 0 & 11.1 & 0 & 50 & 0 & 0 \\
\hline \multicolumn{10}{|c|}{ Cephalosporins } \\
\hline CRO_CTX & $56(9.2)$ & 73.1 & 100 & 100 & 72.7 & 100 & 33.3 & 100 & 100 \\
\hline CAZ & $31(5.1)$ & 100 & 100 & 100 & 100 & 100 & NT & 100 & 100 \\
\hline CXM & $29(4.7)$ & 100 & NT & NT & 0 & NT & 0 & NT & NT \\
\hline \multicolumn{10}{|c|}{ Carbapenems } \\
\hline IPM & $39(6.4)$ & 0 & NT & 20 & 0 & NT & 0 & NT & 0 \\
\hline MEM & $25(4.1)$ & 0 & 0 & 83.3 & 0 & 0 & NT & 0 & 0 \\
\hline \multicolumn{10}{|l|}{ Tetracyclines } \\
\hline TET & $23(3.8)$ & 33.3 & NT & 50 & NT & NT & 60 & NT & 100 \\
\hline DOX & $16(2.6)$ & 50 & 100 & NT & 0 & NT & 0 & NT & NT \\
\hline \multicolumn{10}{|l|}{ Penicillin } \\
\hline Augmentin & $19(3.1)$ & 100 & 100 & 100 & 100 & 100 & NT & NT & 100 \\
\hline OXA & $13(2.1)$ & 100 & NT & NT & 100 & NT & 83.3 & NT & NT \\
\hline PIP & $12(2.0)$ & 100 & NT & NT & 100 & 100 & NT & NT & NT \\
\hline \multicolumn{10}{|l|}{ Macrolides } \\
\hline CLR & $18(2.9)$ & 62.5 & 75 & NT & NT & NT & 16.7 & NT & NT \\
\hline ERY & $14(2.3)$ & 100 & 100 & NT & 0 & NT & 0 & NT & NT \\
\hline \multicolumn{10}{|c|}{ Others (lincosamides, chloramphenicol and glycopeptides) } \\
\hline CLI & $37(6.1)$ & 78.9 & 33.3 & NT & 100 & NT & 27.3 & NT & NT \\
\hline $\mathrm{CHL}$ & $34(5.6)$ & 33.3 & 100 & 100 & 81.8 & 100 & 0 & NT & 100 \\
\hline VAN & $16(2.6)$ & 100 & NT & 14.3 & NT & NT & NT & NT & NT \\
\hline
\end{tabular}

EC: E. coli; KP: K. pneumonae; SA: S. aureus; ECp: Enterococcus spp; EB: Enterobacter spp; MS: Morganella spp; SM: S. marcescens; SP: Salmonella spp CIP: ciprofloxacin; NOR; norfloxacin; GEN: gentamycin; AMK: amikacine; CRO_CTX: ceftriaxone-cefotaxime; CAZ: ceftazidime; CXM: cefuroxime; IPM: impinem; MEM: meropenem; TET: tetracycline; DOX: doxycycline; OXA: oxacyline; PIP: piperacillin; CLR: clarithromycin; ERY: erythromycin; CLI: clindamycin; CHL: chloramphenicol; VAN: vancomycin. NT: Not tested

Table 4 Multidrug antimicrobial resistance (MDR) of the bacterial isolates from patients samples

\begin{tabular}{llllr}
\hline Bacteria & Occurrence & Resistance (n) & \multicolumn{2}{l}{ MDR (n, \%) } \\
\hline Escherichia coli & 43 & 38 & 26 & 68.42 \\
Enterobacter spp & 8 & 7 & 3 & 42.86 \\
Enterococcus spp & 11 & 8 & 2 & 25.00 \\
Klebsiella oxytoca & 1 & 1 & 0 & 0.00 \\
Klebsiella pneumonae & 17 & 16 & 14 & 87.50 \\
Morganella spp & 3 & 3 & 3 & 100.00 \\
Pseudomonas spp & 2 & 2 & 2 & 100.00 \\
Staphylococcus aureus & 16 & 13 & 1 & 7.69 \\
Salmonella spp & 1 & 1 & 0 & 0.00 \\
CNS & 2 & 1 & 0 & 0.00 \\
Serratia marcescens & 3 & 3 & 3 & 100.00 \\
Streptococcus spp & 2 & 1 & 0 & 0.00 \\
Candida albicans & 7 & 0 & 0 & 0.00 \\
\hline
\end{tabular}

showed transmission of foodborne pathogens, similarities of relative frequencies and resistance genes of isolates to antibiotics between humans and animal isolates [36-39]. However, to date, there is scanty information in the literature on a possible role of animal source food as a cause of developed resistance in eastern D.R. Congo.

The current study identified that the majority of respondents regularly eat ASF, mostly milk (96\%), beef (92.8\%) and chicken (90\%), but also goat meat (78.5\%) and pork (61\%). These ASF are part of the commonly kept livestock species in South Kivu Province, of which Bukavu is the capital city. Researchers reported that $85 \%$ of farmers keep livestock solely or in mixed systems [1]. They further indicated that farmers in South Kivu keep mostly chicken (70.5\%), goats (66.1\%), swine (46.4\%) and cattle (19.6\%) for sale and home consumption. This information corresponds with the responses from patients in our study, who mentioned eating chicken and goat meat 
Table 5 Associations between antibiotic resistance and consumption of ASF

\begin{tabular}{|c|c|c|c|c|c|c|}
\hline \multirow[t]{2}{*}{ ASF } & \multirow[t]{2}{*}{ Consumption level } & \multirow[t]{2}{*}{ n (\%) } & \multicolumn{2}{|l|}{ Univariable } & \multicolumn{2}{|l|}{ Multivariable } \\
\hline & & & O.R. (95\% C.I.) & $P$ value & O.R. (95\% C.I.) & $P$ value \\
\hline \multicolumn{7}{|c|}{ Ciprofloxacin } \\
\hline \multirow[t]{2}{*}{ Beef } & Low & $132(62.0)$ & $0.875(0.381-2.011)$ & 0.753 & $0.737(0.542-1.002)$ & 0.051 \\
\hline & High & $67(31.5)$ & Reference & & Reference & \\
\hline \multirow[t]{2}{*}{ Chicken } & Low & $172(80.8)$ & $1.689(0.505-5.645)$ & 0.395 & $1.414(0.965-2.071)$ & 0.076 \\
\hline & High & $26(12.2)$ & Reference & & Reference & \\
\hline \multirow[t]{2}{*}{ Goat meat } & Low & $126(59.2)$ & $0.800(0.304-2.106)$ & 0.651 & $0.996(0.716-1.385)$ & 0.981 \\
\hline & High & $40(18.8)$ & Reference & & Reference & \\
\hline \multirow[t]{2}{*}{ Pork } & Low & $55(25.8)$ & $0.378(0.128-1.112)$ & 0.077 & $0.743(0.560-0.985)$ & 0.039 \\
\hline & High & $76(35.7)$ & Reference & & Reference & \\
\hline \multirow[t]{2}{*}{ Milk } & Low & 70 (32.9) & $1.412(0.528-3.774)$ & 0.492 & $0.915(0.680-1.230)$ & 0.556 \\
\hline & High & $135(63.4)$ & Reference & & Reference & \\
\hline \multicolumn{7}{|l|}{ Gentamicin } \\
\hline \multirow[t]{2}{*}{ Beef } & Low & $19(46.3)$ & $0.921(0.333-2.545)$ & 0.874 & $0.839(0.597-1.179)$ & 0.311 \\
\hline & High & $22(53.7)$ & Reference & & Reference & \\
\hline \multirow[t]{2}{*}{ Chicken } & Low & $35(85.4)$ & $3.214(0.626-16.506)$ & 0.162 & $1.176(0.757-1.827)$ & 0.470 \\
\hline & High & $6(14.6)$ & Reference & & Reference & \\
\hline \multirow[t]{2}{*}{ Goat meat } & Low & $32(78.0)$ & $0.914(0.236-3.539)$ & 0.897 & $0.849(0.569-1.266)$ & 0.422 \\
\hline & High & $9(22.0)$ & Reference & & Reference & \\
\hline \multirow[t]{2}{*}{ Pork } & Low & $21(51.2)$ & $1.705(0.507-5.729)$ & 0.389 & $0.954(0.677-1.343)$ & 0.787 \\
\hline & High & $20(48.8)$ & Reference & & Reference & \\
\hline \multirow[t]{2}{*}{ Milk } & Low & $13(31.7)$ & $0.234(0.059-0.924)$ & 0.038 & $0.717(0.499-1.030)$ & 0.072 \\
\hline & High & $28(68.3)$ & Reference & & Reference & \\
\hline \multicolumn{7}{|l|}{ Levofloxacin } \\
\hline \multirow[t]{2}{*}{ Beef } & Low & $16(50)$ & $1.005(0.355-2.843)$ & 0.993 & $0.690(0.533-0.893)$ & 0.005 \\
\hline & High & $16(50)$ & Reference & & Reference & \\
\hline \multirow[t]{2}{*}{ Chicken } & Low & $28(87.5)$ & $1.062(0.286-3.945)$ & 0.929 & $1.965(1.370-2.820)$ & 0.0001 \\
\hline & High & $4(12.5)$ & Reference & & Reference & \\
\hline \multirow[t]{2}{*}{ Goat meat } & Low & $25(78.1)$ & $2.133(0.483-9.379)$ & 0.316 & $1.293(0.950-1.758)$ & 0.102 \\
\hline & High & $7(21.9)$ & Reference & & Reference & \\
\hline \multirow[t]{2}{*}{ Pork } & Low & $15(46.9)$ & $0.185(0.033-1.020)$ & 0.053 & $0.828(0.648-1.058)$ & 0.132 \\
\hline & High & $17(53.1)$ & Reference & & Reference & \\
\hline \multirow[t]{2}{*}{ Milk } & Low & $10(31.3)$ & $3.294(0.962-11.282)$ & 0.058 & $1.257(0.951-1.660)$ & 0.108 \\
\hline & High & $22(68.8)$ & Reference & & Reference & \\
\hline Ceftriaxone- & xime & & & & & \\
\hline Beef & Low & $18(51.4)$ & $1.905(0.553-6.555)$ & 0.307 & $1.190(0.934-1.516)$ & 0.160 \\
\hline & High & $17(48.6)$ & Reference & & Reference & \\
\hline Chicken & Low & $33(94.3)$ & $2.059(0.220-19.251)$ & 0.527 & $0.899(0.536-1.507)$ & 0.685 \\
\hline & High & $2(5.7)$ & Reference & & Reference & \\
\hline Goat meat & Low & $24(68.6)$ & $0.149(0.033-0.667)$ & 0.013 & $0.618(0.471-0.812)$ & 0.001 \\
\hline & High & $11(31.4)$ & Reference & & Reference & \\
\hline Pork & Low & $16(45.7)$ & $0.265(0.046-1.517)$ & 0.136 & $0.808(0.631-1.034)$ & 0.091 \\
\hline & High & $19(54.3)$ & Reference & & Reference & \\
\hline Milk & Low & $6(17.1)$ & $0.897(0.160-5.023)$ & 0.902 & $1.009(0.726-1.401)$ & 0.958 \\
\hline & High & $29(82.9)$ & Reference & & Reference & \\
\hline
\end{tabular}


Table 6 Influence of the number of ASF frequently eaten on antibiotic resistance scores

\begin{tabular}{|c|c|c|c|c|c|c|c|}
\hline \multirow{2}{*}{$\begin{array}{l}\text { Distinct types of } \\
\text { ASF eaten }\end{array}$} & \multirow[t]{2}{*}{ n (\%) } & \multirow[t]{2}{*}{ ASF groups } & \multicolumn{4}{|c|}{ Antimicrobial resistance } & \multirow[t]{2}{*}{$P$ value } \\
\hline & & & $\mathbf{n}$ & Within group $\%$ & Sum of Scores & Mean Scores & \\
\hline 0 & $7(5.5)$ & & & & 2.22 & 0.32 & 0.05 \\
\hline \multirow[t]{6}{*}{1} & $30(23.8)$ & & & & 18.89 & 0.63 & \\
\hline & & Beef (B) & 8 & 11.9 & & & \\
\hline & & Goat meat (G) & 4 & 6.0 & & & \\
\hline & & Chicken (C) & 2 & 3.0 & & & \\
\hline & & Milk (M) & 42 & 62.7 & & & \\
\hline & & Pork (P) & 11 & 16.4 & & & \\
\hline \multirow[t]{8}{*}{2} & $50(39.7)$ & & & & 19.67 & 0.39 & \\
\hline & & BM & 29 & 46.0 & & & \\
\hline & & $\mathrm{BP}$ & 5 & 7.9 & & & \\
\hline & & GM & 5 & 7.9 & & & \\
\hline & & GP & 4 & 6.3 & & & \\
\hline & & $C M$ & 6 & 9.5 & & & \\
\hline & & $\mathrm{CP}$ & 4 & 6.3 & & & \\
\hline & & PM & 10 & 15.9 & & & \\
\hline \multirow[t]{8}{*}{3} & $34(27.0)$ & & & & & & \\
\hline & & BGM & 3 & 7.3 & 20.67 & 0.61 & \\
\hline & & $\mathrm{BCM}$ & 4 & 9.8 & & & \\
\hline & & $\mathrm{BCP}$ & 2 & 4.9 & & & \\
\hline & & BPM & 11 & 26.8 & & & \\
\hline & & GCM & 1 & 2.4 & & & \\
\hline & & GPM & 17 & 41.5 & & & \\
\hline & & CPM & 3 & 7.3 & & & \\
\hline \multirow[t]{4}{*}{4} & $5(4.0)$ & & & & 1.56 & 0.31 & \\
\hline & & BGPM & 1 & 16.7 & & & \\
\hline & & $\mathrm{BCGP}$ & 3 & 50.0 & & & \\
\hline & & CGPM & 2 & 33.3 & & & \\
\hline
\end{tabular}

more than pork. The higher carcass weight of cattle could explain the low percentage of kept units against its high consumption among the respondents in the current study.

The high percentages of kept livestock do not always reflect the quantity of ASF eaten at the household level. The D.R. Congo is among the least consumers of ASF in the world with $5.2 \mathrm{~kg} / \mathrm{capita} /$ year for beef, 0.6 for milk and 0.1 for eggs [13]. In contrast, we observed in this study much higher ASF consumption in Bukavu than for the country average. Consumption of beef $(13.97 \mathrm{~kg} /$ capita/year) and milk (14.21 kg/capita/year) for high consumers was comparable to some high ASF consumers in Sub-Saharan Africa. This includes the Republic of Congo, Benin and Kenya; although the latter has a much higher consumption of milk per capita (79.7 kg/year) [13]. Low consumers indicated about $4.6 \mathrm{~kg} /$ year for beef and $2.9 \mathrm{~kg}$ for milk, which is comparable to national levels. Chicken consumption was reported to be between 2.5 and $9.3 \mathrm{~kg} /$ capita/year, while it was between 2.0 and $9.2 \mathrm{~kg} /$ capita/ year for pigs and between 3.0 and 9.1 for goat meat for low and high consumers, respectively. These reported consumption levels were generally higher than observed in Sub-Saharan Africa, except for poultry where low eaters are below the $6.7 \mathrm{~kg} / \mathrm{capita} /$ year reported in Africa [2].

High and regular consumption of ASF from animals treated with antibiotics could pose a risk for humans to develop resistances [19], because the livestock industry uses a wide range of antibiotics also used in human medicine to fight various pathogens such as E. coli, Salmonella and S. aureus [20, 21, 39]. These authors describe ASF consumption as one of the routes for transmission of antibiotic resistance from animals to human, alongside with drinking contaminated water. The main groups of antibiotics used in livestock treatment include sulfonamides, sulfadiazine, lincosamides, tetracyclines, penicillin, betalactams, cephalosporins, quinolones, fluoroquinolones and macrolides/azalides aminoglycosides $[22,23]$. 
We found that for E. coli, Klebsiella spp, Enterobacter spp, Shigella spp and Salmonella spp a high proportion of isolates showed resistance to certain antibiotics including cotrimoxazole, erythromycin and ampicillin, similar to what has been reported in Bukavu [17]. The most commonly isolated microorganisms in patients' samples were E. coli (37.1\%), K. pneumonae (14.7\%), and S. aureus (13.8\%). These microorganisms are among the most pathogenic in livestock production and reported multi-drug resistant among bacteria in ASF [39]. Köck et al. [39] reported the presence of livestock associated methicillin resistant $S$. aureus in patients' samples, while Wu et al. [38] have reported a similar trend with resistant genes of E. coli. This finding is of high public health relevance because of the risk of human microbial pathogens gaining resistance to antimicrobials, especially in SubSaharan Africa. We found that E. coli isolates were resistant to most antibiotics tested, except Meropenem (100\% susceptible), Imipenem (100\% susceptible), and to some extent tetracycline (66.4\% susceptible), chloramphenicol (66.4\%), and amikacin (70\% susceptible). Other researchers working on patients' urinary tract infections [25], acute diarrhoea [26] and strains occurring in humans, animals or food $[27,28]$ reported also a resistance of $E$. coli to multiple drugs. Here, $68 \%$ of $E$. coli isolates were found to be multidrug resistant (to more than 3 antibiotic families). A similar trend was observed in Bukavu City by previous research that associated the observed multidrug resistance of several micro-organisms including E.coli $[7,32,40]$. They explained it with an irrational prescription and/ or use of antibiotics in the province. Klebsiella pneumonae and Morganella spp, Pseudomonas, and Serratia spp were also found to be multidrug resistant as reported in other studies [17, 33, 34]. These researchers associated the development of multidrug resistance to prior exposure to a group of antibiotics in the classes of fluoroquinolones, penicillin, glycopeptides, carbapenems and cephalosporins among other risk factors [17, 34, 35]. Isolates of Salmonella spp were found to be resistant to amoxicillin (88.3\%), augmentin (95\%), chloramphenicol $(92 \%)$ cotrimoxazole $(90 \%)$, doxycycline $(73 \%)$ and negram (98\%) [18]. The resistance of the bacterial isolates to antibiotics, although attributed to wrongful administration/uptake, could also be due to environmental contact, or consumption of food already contaminated by antibiotics [24].

We investigated the possible associations between resistances to antibiotics observed in microorganisms isolated from patients with their eating habits of animal source foods (ASF). The influence varied for different antibiotics and the type of ASF consumed. Resistance to ciprofloxacin was lower for patients eating less beef $(0.875, \mathrm{CI}: 0.381-2.011)$, goat meat $(0.800$,
C.I: $0.304-2.106)$ and pork (0.378, CI $0.128-1.112)$ in the univariable analysis. In the multivariable analysis, only low pork consumption (O.R.: 0.743, CI 0.560 - 0.985) was found with significantly lower odds of resistance to ciprofloxacin than high consumption. Fluoroquinolones, the antibiotic family of ciprofloxacin, are widely used in monogastric livestock production. The common forms used are marbofloxacin, difloxacin and enrofloxacin. Ciprofloxacin is a major metabolite of the latter and studies have reported a high concentration of fluoroquinolones in the dust of pig barns $(>10 \mathrm{ng} / \mathrm{mg})$ and in pork samples $(315.3 \mu \mathrm{g} / \mathrm{kg} ; 11.39 \mu \mathrm{g} / \mathrm{kg}$ and $27.02 \mu \mathrm{g} / \mathrm{kg}$ for ciprofloxacin, norfloxacin and ofloxacin respectively) [28, 29]. This could influence the transfer of resistant microbiota to consumers. In the same antibiotic family, our study reported a significant influence of beef (O.R. 0.69; CI 0.533 - 0.893) and chicken consumption (O.R. 1.965; C.I. $1.3970-2.820$ ) on the risk of resistance to levofloxacin. This is in line with findings by Kyuchukova et al. [30], who reported a high concentration of levofloxacin $(428 \mu \mathrm{g} / \mathrm{kg})$ in chicken meat samples from the end of antibiotic treatment up to 8 days, although the concentration tends to decrease with time $(56 \mu \mathrm{g} / \mathrm{kg})$. These findings suggest a high risk to public health and add to the hypothesis that these food products could be causing resistance in humans if withdrawal periods are not observed. Indeed, resistance to antimicrobials can originate from sub-therapeutic and therapeutic use of antibiotic when withdrawal periods are not observed and, render patients' treatment more complex.

Patients drinking less milk had significantly $(p<0.05)$ lower odds of resistance $(0.234$, CI $0.059-0.924)$ to gentamycin than those drinking high volumes. The difference was significant in the univariable but not in multivariable analysis. Gentamycin is commonly used in lactating dairy cows to treat intramammary infections. Previous studies show about $12.5 \%$ resistance of $S$. aureus isolated from milk to this antibiotic [31]. They further report $55.5 \%$ and $44.4 \%$ of milk samples containing residues of gentamycin 6 days after the treatment. This further explains the risk for consumers by animal-derived food, especially from the informal sector, where compliance with quality testing and withdrawal period are not observed.

We further investigated the possible influence of combining more than one ASF on the developed resistance to antibiotics. Results show that from eating 1 to 3 ASF the sum of scores for resistance to antibiotics increases. This could be explained by the influence of different ASF to different antibiotics, hence increasing the chance of resistance with the increase the number of ASF eaten during the same week. However, patients who reported eating four ASF during the same week had the lowest score. This could be due to the small number (only 5) 
of individuals in this category, not allowing to make a decisive inference. Hence, the risk for public health rises since the consumption of multiple antibiotic contaminated food may transmit multi-drug resistant bacteria to consumers. Marshall and Ley [19] explain that food from many different animal sources not only could contain high quantities of resistant bacteria but also point out the difficulty to attribute developed resistance in humans to the specific antibiotic. Hence, molecular techniques are able to confirm the identity of the microbial resistance gene in animals and humans [19]. In the context of Bukavu city, much remains to be done to understand the transmission pattern of antibiotic resistance from ASF to humans. An initial step would be the identification and quantification of microbial strains and antibiotic residues found in animal -source -food using molecular techniques.

\section{Conclusion}

Antibiotic usage is described as the cause of bacterial resistance to antibiotics. This study has shown the existence of a high prevalence of resistant bacteria in patients for which frequent consumption of beef, pork, goat meat or milk were significant risk factors. The risk could be reduced by observing withdrawal periods before animals are sold and improving the surveillance of antibiotics use in livestock farms supplying the city.

\section{Acknowledgements \\ Authors express their gratitude to the Department of Engineering for Livestock Management of the Leibniz Institute for agricultural Engineering and Bio economy, e.V. Potsdam for funding the publication of this article. We also thank all health facilities and patients who accepted to participate in the study. We finally thank the Institut Supérieur des Techniques Médicales (ISTM) of Bukavu, D.R. Congo for facilitating access to the selected health facilities.}

\section{Authors' contributions}

BRN, KOB, MTK and KAS developed the study design and obtained the required approvals from the health facilities selected. BRN, NBS, MTK, KAS and KOB planned, carried out and evaluated the data collection process. BRN and KOB analysed the data. NS, KAS and KOB reviewed the manuscript and approved final version.All authors read and approved the final manuscript.

\section{Funding}

Open Access funding enabled and organized by Projekt DEAL.

\section{Availability of data and materials}

All data generated or analysed during this study are included in this published article (and its supplementary information files).

\section{Declarations}

\section{Ethics approval and consent to participate}

This study was reviewed and approved by the Institutional Committee of Ethics in Health Research (Comité Institutionnel d'Ethique de la Santé) of the College of Medical Techniques of Bukavu (ISTM-Bukavu), (reference number: ISTM-BKV/CERPS/CIES/ML/04/2019). All participants signed the consent form, and were informed that their participation was voluntary, anonymous, and they could quit at any time.
Consent for publication

Not applicable.

\section{Competing interests}

Authors declare that they have no competing interests.

\section{Author details}

'Institut Supérieur Des Techniques Médicales (ISTM) de Bukavu, B.P. 3036, Bukavu, Democratic Republic of Congo. ${ }^{2}$ Department of Laboratory Medicine, Provincial Referral General Hospital of Bukavu, Bukavu, Democratic Republic of Congo. ${ }^{3}$ Livestock Production Systems Group, Department of Animal Sciences, Egerton University, Box 536-20115, Njoro, Kenya. ${ }^{4}$ Leibniz Institute for Agricultural Engineering and Bioeconomy (ATB), Max-Eyth-Allee 100, 14469 Potsdam, Germany.

Received: 9 March 2021 Accepted: 8 August 2021

Published online: 26 August 2021

\section{References}

1. Maass BL, Musale DK, Chiuri WL, Gassner A, Peters M. Challenges and opportunities for smallholder livestock production in post-conflict South Kivu, eastern DR Congo. Trop Anim Health and Prod. 2012;44(6):1221-32.

2. Robinson, T. P., \& Pozzi, F. Mapping supply and demand for animal-source food to 2030. FAO, Animal production and health working paper. 2011;2, $1-154$.

3. Udomkun P, Ilukor J, Mockshell J, Mujawamariya G, Okafor C, Bullock R, Vanlauwe $B$. What are the key factors influencing consumers' preference and willingness to pay for meat products in Eastern DRC? Food Sci and Nutr. 2018;6(8):2321-36

4. Appiah GD, Chung A, Bentsi-Enchill AD, Kim S, Crump JA, Mogasale V, Mintz ED. Typhoid outbreaks, 1989-2018: implications for prevention and control. AM J Trop Med Hyg. 2020;102(6):1296-305.

5. Amicizia, D., Micale, R. T., Pennati, B. M., Zangrillo, F., lovine, M., Lecini, E., Panatto, D. Burden of typhoid fever and cholera: similarities and differences. Prevention strategies for European travelers to endemic/epidemic areas. J Prev Med Public Health. 2019; 60(4), E271.

6. Mahangaiko M, Mabi N, Bakana M, Nyongombe U. Food contamination with salmonella and human health in Kinshasa city, Democratic Republic of Congo (DRC). JABs. 2015;2015(94):8809-14.

7. Irenge LM, Kabego L, Kinunu FB, Itongwa M, Mitangala PN, Gala JL, Chirimwami RB. Résistance antimicrobienne de bactéries isolées provenant de patients présentant des infections du sang dans un hôpital de soins tertiaires en République démocratique du Congo. S Afr Med J. 2015;105(9):752-5.

8. Iwu CD, Korsten L, Okoh Al. The incidence of antibiotic resistance within and beyond the agricultural ecosystem: A concern for public health. MicrobiologyOpen. 2020 Jul 25:e1035.

9. Autorité européenne de sécurité des aliments (EFSA). - The European Union Summary Report on antimicrobial resistance in zoonotic and indicator bacteria from humans, animals and food in 2010. EFSA J., 2012, 10(3), $233 \mathrm{pp}$

10. Mensah G.A. - Atelier technique sur l'analyse des risques sanitaires des aliments. In Rapport final de l'atelier. Cotonou- Bénin, 2011, 14 pp. Disponible en ligne : http://www.fao.org/fileadmin/user_upload/agns/pdf/ Rapport_atelier_FAO_OMS_INRAB_Cotonou_dec_2011.pdf

11. Randolph, T. F., Schelling, E., Grace, D., Nicholson, C. F., Leroy, J. L., Cole, D. C., ... \& Ruel, M. Invited review: Role of livestock in human nutrition and health for poverty reduction in developing countries. JAS. 2007, 85(11), 2788-2800.

12. Sanusi, R.A. et Olurin A. Portion and serving sizes of commonly consumed food, in Ibadan, Southwestern Nigeria.. Afr.J. Biomed. Res. 2012; 15:149-158.

13. Speedy AW. Global production and consumption of animal source food. J Nutr. 2003;133(11):4048S-4053S

14. Talaiekhozani A, Alaee S, Ponraj M. Guidelines for quick application of biochemical tests to identify unknown bacteria. AOBR. 2015;2(2):65-82.

15. Bauer AT. Antibiotic susceptibility testing by a standardized single disc method. Am J clin pathol. 1966;45:149-58. 
16. CLSI. Performance Standards for Antimicrobial Susceptibility Testing; Twenty-First Informational Supplement. CLSI document M100-S21. Wayne, PA: Clinical and Laboratory Standards Institute; 2011.

17. Birindwa, A. M., Emgård, M., Nordén, R., Samuelsson, E., Geravandi, S., Gonzales-Siles, L., ... \& Cibicabene, D. High rate of antibiotic resistance among pneumococci carried by healthy children in the eastern part of the Democratic Republic of the Congo. BMC Pediatrics. 2018; 18(1), 361

18. Mitima TK, Birindwa AM, Lupande DM, Mihuhi N, Kivukuto JM, et al. Antibio-résistance des souches de Salmonella spp isolées d'hémocultures à Bukavu en RD Congo. Pan Afr J Med. 2018;29:42.

19. Marshall BM, Levy SB. Food animals and antimicrobials: impacts on human health. Clin Microbiol Rev. 2011;24(4):718-33.

20. Sivagami, K., Vignesh, V. J., Srinivasan, R., Divyapriya, G., \& Nambi, I. M Antibiotic usage, residues and resistance genes from food animals to human and environment: An Indian scenario. J Environ Chem Eng. 2020, 8(1), 102221.

21. Thapa, S. P., Shrestha, S., \& Anal, A. K. Addressing the antibiotic resistance and improving the food safety in food supply chain (farm-to-fork) in Southeast Asia. Food Control. 2020, 108, 106809.

22. Moyane JN, Jideani AIO, Aiyegoro OA. Antibiotics usage in food-producing animals in South Africa and impact on human: Antibiotic resistance. Afr J Microbiol Res. 2013;7(24):2990-7.

23. De Briyne N, Atkinson J, Pokludová L, Borriello SP. Antibiotics used most commonly to treat animals in Europe. Vet Rec. 2014;175(13):325.

24. Kirbis A, Krizman M. Spread of antibiotic resistant bacteria from food of animal origin to humans and vice versa. Int J Food Sci Technol. 2015;5:148-51.

25. Kariuki, S., Revathi, G., Corkill, J., Kiiru, J., Mwituria, J., Mirza, N., \& Hart, C. A. (2007). Escherichia coli from community-acquired urinary tract infections resistant to fluoroquinolones and extended-spectrum beta-lactams. J Infect Dev Ctries, 2007. 1(03), 257-262.

26. Rahman, M. M., Ahmed, P., Kar, A., Sakib, N., Shibly, A. Z., Zohora, F. T., \& Hasan, M. N.. Prevalence, Antimicrobial Resistance, and Pathogenic Potential of Enterotoxigenic and Enteropathogenic Escherichia coli Associated with Acute Diarrheal Patients in Tangail, Bangladesh. FOODBORNE PATHOG DIS. 2020.17 (7). DOI: https://doi.org/10.1089/fpd.2019.2741

27. Sáenz Y, Briñas L, Domínguez E, Ruiz J, Zarazaga M, Vila J, Torres C. Mechanisms of resistance in multiple-antibiotic-resistant Escherichia coli strains of human, animal, and food origins. Antimicrob Agents Chemother. 2004:48(10):3996-4001.

28. Schulz J, Kemper N, Hartung J, Janusch F, Mohring SA, Hamscher G. Analysis of fluoroquinolones in dusts from intensive livestock farming and the co-occurrence of fluoroquinolone-resistant Escherichia coli. Sci Rep. 2019;9(1):1-7.

29. Omotoso, A. B., \& Omojola, A. B. Fluoroquinolone residues in raw meat from open markets in Ibadan, Southwest, Nigeria. International Journal of Health, HAF. 2020; 2(1).

30. Kyuchukova R, Urumova V, Lyutskanova M, Petrov V, Pavlov A. Levofloxacin residues in chicken meat and giblets. Bulg J Vet Med. 2013;16(1):216-9.
31. Martins, K. B., Faccioli, P. Y, Bonesso, M. F., Fernandes, S., Oliveira, A. A., Dantas, A., Maria de Lourdes, R. S. Characteristics of resistance and virulence factors in different species of coagulase-negative staphylococci isolated from milk of healthy sheep and animals with subclinical mastitis. J. Dairy Sci., 2017: 100(3), 2184-2195.

32. Kadima JN, Irenge CA, Mulashe PB, Kasali FM, Wimba P. Antibiogram profile of antibacterial multidrug resistance in democratic Republic of Congo: Situation in Bukavu City Hospitals.

33. Falagas ME, Rafailidis PI, Kofteridis D, Virtzili S, Chelvatzoglou FC, Papaioannou V, Michalopoulos A. Risk factors of carbapenem-resistant Klebsiella pneumoniae infections: a matched case-control study. J Antimicrob Chemother. 2007:60(5):1124-30.

34. Raman G, Avendano EE, Chan J, Merchant S, Puzniak L. Risk factors for hospitalized patients with resistant or multidrug-resistant Pseudomonas aeruginosa infections: a systematic review and meta-analysis. Antimicrob Resist Infect Control. 2018;7(1):1-14

35. Harris PN, Wei JY, Shen AW, Abdile AA, Paynter S, Huxley RR, Paterson DL. Carbapenems versus alternative antibiotics for the treatment of bloodstream infections caused by Enterobacter, Citrobacter or Serratia species: a systematic review with meta-analysis. J Antimicrob Chemother. 2016;71(2):296-306

36. Lawson B, de Pinna E, Horton RA, Macgregor SK, John SK, et al. Epidemiological Evidence That Garden Birds Are a Source of Human Salmonellosis in England and Wales. PLoS ONE. 2014;9(2): e88968. https://doi.org/10. 1371/journal.pone.0088968.

37. Suwono B, Eckmanns T, Kaspar H, Merle R, Zacher B, et al. Cluster analysis of resistance combinations in Escherichia coli from different human and animal populations in Germany 2014-2017. PLoS ONE. 2021;16(1): e0244413. https://doi.org/10.1371/journal.pone.0244413.

38. Köck R, Schaumburg F, Mellmann A, Köksal M, Jurke A, et al. LivestockAssociated Methicillin-Resistant Staphylococcus aureus (MRSA) as Causes of Human Infection and Colonization in Germany. PLoS ONE. 2013;8(2): e55040. https://doi.org/10.1371/journal.pone.0055040.

39. Wu G, Day MJ, Mafura MT, Nunez-Garcia J, Fenner JJ, et al. Comparative Analysis of ESBL-Positive Escherichia coli Isolates from Animals and Humans from the UK. The Netherlands and Germany PLoS ONE. 2013;8(9): e75392. https://doi.org/10.1371/journal.pone.0075392.

40. Ntizala, A. B., Mulume, T. Y., Runyeruka, B. L., \& Kishabongo, A. S. (2020) Antibiotic Dispensing Practices in Community Pharmacies: A Major Health Concern in the Eastern Democratic Republic of Congo. Journal of Pharmaceutical Research International, 33-44

43. Naing $L$, Winn T, Rusli BN. Practical issues in calculating the sample size for prevalence studies. Arch Orofac Sci. 2006;1:9-14.

42. Daniel WW, Cross CL. Biostatistics: a foundation for analysis in the health sciences. Wiley; 2018.

\section{Publisher's Note}

Springer Nature remains neutral with regard to jurisdictional claims in published maps and institutional affiliations.

\footnotetext{
Ready to submit your research? Choose BMC and benefit from:

- fast, convenient online submission

- thorough peer review by experienced researchers in your field

- rapid publication on acceptance

- support for research data, including large and complex data types

- gold Open Access which fosters wider collaboration and increased citations

- maximum visibility for your research: over 100M website views per year
}

At BMC, research is always in progress.

Learn more biomedcentral.com/submissions 